\title{
Research on the Evolution of Management Concepts of Sustainable Tourism and Hospitality Development in the Regions
}

\author{
Oleg A. Bunakov ${ }^{1}$, Natalia A. Zaitseva ${ }^{2}$, Anna A. Larionova ${ }^{2}$, Alex D. Chudnovskiy ${ }^{3}$, Marina A. Zhukova ${ }^{3}$ \& \\ Vadim A. Zhukov ${ }^{3}$ \\ ${ }^{1}$ Kazan (Volga region) Federal University, Kazan, Russia \\ ${ }^{2}$ Plekhanov Russian University of Economics, Moscow, Russia \\ ${ }^{3}$ State University of Management, Moscow, Russia \\ Correspondence: Anna A. Larionova, Plekhanov Russian University of Economics, 117997, Moscow, Stremyany \\ per., 36. Russia. E-mail: annla@list.ru
}

Received: June 13, 2015 Accepted: June 21, 2015 Online Published: June 29, 2015

doi:10.5539/jsd.v8n6p39 URL: http://dx.doi.org/10.5539/jsd.v8n6p39

\begin{abstract}
The relevance of the issues of the working out of management of sustainable tourism and hospitality development in the regions stipulated by the necessity of integrated approach to assessing the impact of tourism on the socio-economic aspects of the regions progress. The purpose of the article is to develop a methodology for managing sustainable development of tourism and hospitality in the regions. The leading approach to the study of this problem is evaluation of the scale of tourism development and its impact on the region, and then determination of the appropriate indicators for each measurement and the analysis of assets and resources, related to the development of tourism and hospitality, that allows a comparison with other regions and countries. The article covers the questions of change of scientific approaches to the assessment of the essence of the concept of "sustainable tourism development", identifies and describes the main factors affecting the management of sustainable development of tourism and hospitality in the region. The article also reveals that if the connection between tourism and other sectors of the national economy can not be built, a significant part of the development potential of the tourism actions may be lost. Article materials represent a practical value to designers in the field of tourism and marketing specialists trying to develop offers that are adapted to the needs of the target markets.
\end{abstract}

Keywords: sustainable development, tourism, hospitality, and tourism development in the regions, management concepts

\section{Introduction}

In recent years the number of international organizations and scientists dealing with the concept of sustainable development has been increasing. The efforts are directed both on the general development and on special sectors or issues. A significant part of the scientists has concentrated on the research of sustainable tourism development.

Already in 1999, the Worldwide Tourism Organization (UNWTO) compiled a list of about 100 books and more than 250 articles on the sustainable tourism development. In spite of these research works and their merits and usefulness, the results remain underutilized (Russiatourism, 2015).

The main reason for the creation of the methodology is that sustainable tourism development in the developing countries depends on the fast growing of the tourism importance in the industrialized countries (Buckingham, 2008). Tourism appeared in a new quality of one of the main socio-economic sectors and was growing at annual rate of $4-5 \%$ in the second part of XX century.

According to statistics, the combination of domestic and external types of tourism can be referred to the large-scale industry. In 2013 tourism generated the income of \$3,4 trillion, that formed 10,9\% of GDP in the world. About 230 of employees turned out to be engaged in the tourism sector that provided about $\$ 700$ billion in tax revenue (Ko, 2005).

Developing countries acquire the increasing share of international tourists as they have improved transport 
infrastructure and developed high-quality services. Their share in the international tourist's flow increased from $28 \%$ in 1990 to $41 \%$ in 2013 (Mingaleva \& Bunakov, 2014).

Finally, tourism brings much-needed foreign currency to developing countries. It allows financing the import of raw material required for the economic development and diversification of economy in general (Dzhandzhugazova, 2013).

Despite the great potential, some economic systems have not been able to realize the benefits of growth in the tourism industry. For example, a lot of Latin countries take into account only international tourist's trips, while increasing number of people are taking trips around the country (in many cases several times a year).

Until 2009 America has seen an annual growth of 51\% in trips for the last 20 years. Though, nowadays there seems to be a long-lasting decline (Frechtling, 1999).

Nowadays, some countries face the challenges with the tourism development stability. Such phenomenon is particularly common on the islands such as Tahiti or Caribbean where human presence puts pressure on marine life and locals do not take advantage of the tourist activity. On average, $60-90 \%$ of the price that tourists pay for their vocation passes to the largest transnational corporations that own airlines and hotels.

It confirms the relevance of the creation of the management of sustainable development of tourism and hospitality in the regions.

\section{Methodological Framework}

\subsection{Methodical Aspects of the Management of Sustainable Development of Tourism and Hospitality in the Regions}

The concept of "sustainable tourism development" itself is far from being successively used. UNWTO notes that "sustainable tourism development meets the needs of tourists and hosts, protecting and enhancing the opportunities for the future progress. It calls for the transfer to all-resources-management in such a way, that economic, social and aesthetic needs to be fulfilled without breaking the cultural integrity and ecological processes."

However, the notion is flexible enough, that has allowed a lot of new approaches and interpretations to appear. For instance, UNWTO in the framework of "sustainable tourism development" explores the problems, connected with:

- development of rural and ecological types of tourism with the impact on the environment;

- cultural and natural heritage;

- urban development;

- development of alternative tourism;

- wildlife conservation and creation of national parks, etc.

Such diversity of approaches concerning sustainable tourism development and complexity of this concept come to the fact that some scientists even question its usefulness, for example, Middleton and Hawkins (Souty, 2003).

A larger share of researchers, evaluating the tourism activities, often deals only with one component. For example, the impact of tourism on economy is a rate, based on the data on the number of arrivals, the average duration of stay and other economic indicators. In order to evaluate the tourism activities and its effect on national economy properly, some researchers have tried to create specialized methodologies (for example, Fretchling) (Hawkins \& Middleton, 1998).

Other researchers have emphasized on assessing of tourism resources (natural, cultural, etc.). Further, the authors lay more stress on the creation of the sustainable tourism development methodology.

Miller drew attention to the development of indicators that measure tourism sustainability as well as highlighted the main problems: environmental protection, locals' employment in the development of tourist infrastructure, financial outflow and client's contentment (Miller, 2001).

Another famous attempt to create comprehensive methodology of evaluation of possibilities of sustainable tourism development was made by Ko T. G. (Ko, 2005). After review of existing literature, he came to conclusion that "methods of systematic evaluation of sustainability are not in use in tourism nowadays". He found that most of the studies on the sustainable tourism development are descriptive, based on the quality data and subjective in conclusions. Thus, there is a lack of clear methodology of assessing the problems of sustainability in the tourist sector. Ko offers conceptual framework for the evaluation of the sustainability of the 
tourism development, based on eight measurements:

- political component;

- economical component;

- socio-cultural component;

- manufacturing aspects;

- impact on the environment;

- ecosystem quality;

- biodiversity;

- environmental policy.

Each measurement is assessed on the basis of quantitative and qualitative indicators that are measured and grouped so as to evaluate the sustainability of the tourist's place.

Ko T.G. (2005) asserts that the problems of sustainable tourism development vary from one place of tourism to another. Consequently, he offers to determine the scale, indicators and methods of collecting the data. The regions could be changed to adapt the methodology to the specific conditions of each place of tourism. At the same time, despite the merits of this methodology, it limits the comparability of results.

\subsection{Functions and Tasks of the Methodology of the Management of the Sustainable Tourism and Hospitality Development in the Regions}

For the connection between the tasks and the potential in sustainable tourism there is a need of methodology that would allow covering the complex issues, described above. In addition, such methodology may suggest some solutions to let developing countries, much-dependent on tourism, to enhance the sustainability of the sector.

Functions of such methodology:

- methodology should be able to reveal the problems of sustainability in the tourism destination;

- the usage of rates and indicators, important for policy.

Methodology has to allow politicians making reasonable decisions and improve the prospects of sustainable tourism in their countries.

To create such methodology the following steps have been taken.

Firstly, seven key conditions were chosen:

- tourism assets (potential);

- international calls (activity);

- advantages, linked with tourism;

- disadvantages, linked with tourism;

- ecological and social stability;

- general infrastructure;

- other attractive aspects (low price, human resources, risk, etc.).

Secondly, as soon as a scale becomes clear, the next step will include finding of appropriate indicators for each measurement.

Thirdly, indicators must include the possibility to do a comparative analysis with other countries.

It goes without saying, that each country that considers the development of their tourism sector should accurately evaluate their tourism-related assets and resources. Tourism assets are basically the main factors that motivate tourists in their choice of the destination. Therefore, the assets of tourism and hospitality should be thoroughly evaluated before making a decision, whether a given region has a potential for development and expansion of tourism, and if so, what actions have to be taken to develop it.

Researches on tourism assets evaluation are not numerous in modern literature (Honek, 2001; Gollub, et al., 2003). Difficulties in interpretation of different quantitive tourism assets indicators are stepping forward now. Normally tourism assets are grouped into two categories. They are natural resources and cultural assets.

One of the best ways to increase economical profit of tourism is to involve it into national economy establishing 
strong links between tourism and other sections of economy including agriculture, fishing, manufacturing, construction. If tourism sector uses products and services produced within a country it will strengthen these scopes of activity and provide an extra profit. The main drawback is possible missed opportunities.

If the links to other national economy sectors are impossible a significant part of the tourism activity development potential is lost.

The losses include both major foreign currency loss and other hidden costs of tourism activity.

The losses include two major components that we must take into account in order to get a true concept of it.

1) Internal losses or losses due to tourism activity inside the economic space of tourism services supplier;

2) External losses or alternative costs outside the economic space of tourism service supplier. They do not stay inside the country and that is why it is more difficult to measure them.

Hence, in order to determine tourism development strategy we should work out indicators for losses calculation appropriate for any type of country development.

Other important aspect of sustainable tourism development is a degree of tourism influence on society. Environment social parameter defines quantity and variants of residents' participation in different tourist actions. Ecological aspect estimates introduction of ecological quality standards coordinated by appropriate international organizations and projects and tourism profits distribution for prevention of deterioration of destination place.

It should be mentioned here that the problem of sustainable tourism development should be analyzed fully, in complex. For example, even though the tourism activity has low loss effect, it does not necessarily mean that the local population will benefit from this activity as local operators cannot create enough jobs or set low wages. In addition, environment sustainability does not guarantee that tourism activities are properly taxed for replenishment and the environment (Holtzman, 2008).

\section{Results}

As a consequence of the research the following factors of sustainable tourism and hospitality development management in regions were defined.

\subsection{Image of Russian Hotel Business It's Forming and Promotion Abroad}

Incoming tourism is greatly influenced by expert evaluation. One of the most authoritative estimations in this sphere is World Economic Forum (WEF). In 2012 Russia has fallen on 4 positions in this rating or from $59^{\text {th }}$ to $63^{\mathrm{d}}$ (Polzer, 2008). The main factors of this rating downgrade are unfavorable infrastructure of ground transportation and system of travelling and tourism regulation. At the same time among the factors of Russian tourism competitiveness rich natural resources and cultural assets were highlighted in the Forum. In 2013 and 2014 political sanctions were added to the negative factors. Due to these sanctions image of Russia as famous tourist destination was ruined.

\subsection{Demographic Factors and Staffing of Tourism and Hospitality Development}

Generally demographic situation is quite difficult. Working-age population declines. Moreover, in its structure the following negative trends are noticed: share of employable people in the age up to 30 declines, so the employers have to hire an older generation (people in age from 50) (Becker \& Brian, 2001). Besides, new workforce quality structure is changing: the share of professionals with specialized education among graduates of high schools and universities does not grow and in the future will be significantly reduced (this year the last graduates which entered institutes without passing GEF enter the labor market, in 2015 there will be the first bachelor graduates taught according to the third generation standards (FGOS), the number of which is less, than specialist graduates) (Delia, 2011).

According to the data of Russian Federal State Statistics Service of $1^{\text {st }}$ January 2014 there 31 million of young people in age up to 29 in Russia. Whereas 41 million could be attributed to the generation X and 35 million could be attributed to the baby boomers. The calculations show that in 2010-2020 we should expect a significant reduction of educational potential of the employed due to the retirement of relatively numerous postwar generation representatives which have quite high education degree. During the period from 2007 to 2016 educational potential of economically active population is expected to decline on 160 million person-year or on other words. As result these losses can be even more serious if we take inti account the quality of modern education.

\subsection{Imperfection of the Tourism and Hospitality Development Normative Regulation on the Base of Professional Standards}


For the purpose of reglamentation of independent appraisal of qualifications for the compliance to professional standards two legislative proposals 'About the independent qualification appraisal' and 'About the introduction of changes into the Part II of the Internal Revenue Code of RF (IRC RF) have been worked out and now are on the stage of the social discussion. If we formulate the basic aims of the realization of the State politics in the sphere of qualification standardization and certification we may narrow them down to the following: the increase of social mobility of the personnel; professional education and training quality appraisal; initiation of the conditions for personnel participation in in permanent education; strengthening of trade unions role in professional qualification development ; establishment and (or) confirmation of competitor qualification to the professional standards clauses; increasing competitiveness of employees which have undergone an independent qualification appraisal in the labor market. Under these conditions, with the strengthened role of trade unions the State role consists in developing basic methodological tools, which are essential for the process of qualifications certificating, including working out and affirmation of the template form of qualification certification; forming and maintenance of federal information system, including information about the documents adopted by the Professional Qualifications coordinating authorities, Professional Qualifications Counsels (Ministerstvo truda, 2015); about qualification appraisal centers; about the list of professional qualifications, which are adopted by these unities; about the issued qualification certificates; about the appellate commissions (NARK, 2015). The collection of documents and materials for independent appraisal and qualification certification is worked out by the Labor Ministry, RSPP, the National Agency for Qualification Development and the Research Institute of Labor and Social Insurance. In these documents we may read the following; 'The adopted model of certification of qualifications primary role of the organizers of specific occupations is given the all-Russian branch (interbranch) associations of employers, as well as the largest vertically integrated companies and public corporations'.

\section{Conclusion}

The present research allows us to sum up that in the process of implementing sustainable tourism development in regions strategies there is not any complex approach aimed at calculations of multidimensionality of tourism and hospitality essence. As a result involvement of activity aimed at regional tourism development without taking into account all the interrelated factors. Besides, sustainable tourism development in regions is effected by negative factors as worsened image of Russian tourism, consequences of demographic changes, changes in the system of personnel training and other factors that have a direct influence on sustainable tourism and hospitality development in regions.

\section{References}

Becker, \& Brian, E. (2001). The HR scorecard: linking people, strategy, and performance. Boston, Mass. Harvardbusinessschoolpress cop.

Buckingham, M. (2008). Leader strength. Leadership Excellence, 25(8), 16-17.

Delia, V. (2011). Professionalizing in the conditions of modern system of innovative education. Moscow, De-Poe.

Dzhandzhugazova, E. A. (2013). New Forms and Possibilities for Promotion of Russian National Parks in the Internet Environment. Middle-East Journal of Scientific Research, 16(9), 1238-1244.

Dzhandzhugazova, E. A. (2013). Particularities of Creation and Promotion of New Ideas in Social Network Space. World Applied Sciences Journal, 27, 79-84.

Frechtling, D. C. (1999). The tourism satellite account: foundations, progress and issues. Tourism Management, 20, 163-170. http://dx.doi.org/10.1016/S0261-5177(98)00103-4

Gollub, J., Hosier, A., \& Woo, G. (2003). Leakages and Linkages in the Tourism Sector. In WTO (Ed.), Studies in relation to trade negotiations on tourism services. Madrid: WTO.

Hawkins, R., \& Middleton, V. (1998). Sustainable tourism. A marketing perspective.

Holtzman, Y. (2008). Innovation in research and development: tool of strategic growth. Journal of Anagement Development, 27(10), 1037-1052.

Honek, D. (2001). Tourism and the General Agreement on Trade and Services. In UNLDC (Ed.), Tourism in the Least Developed Countries. Geneva: UNLDC.

Ko, T. G. (2005). Development of a tourism sustainability assessment procedure: a conceptual approach. Tourism Management, 26(3), 431-445. http://dx.doi.org/10.1016/j.tourman.2003.12.003

Miller, G. (2001). The development of indicators for sustainable tourism: results of a Delphi survey of tourism 
researches. Tourism Management, 22, 351-362. http://dx.doi.org/10.1016/S0261-5177(00)00067-4

Mingaleva, Z., \& Bunakov, O. (2014) Innovative ways of using the tourist potential as the basis of territories development. Life Science Journal, 11(6), 315-317.

Ministerstvo truda. (2015, May 11). Reestr sovetov po professional'nym kvalifikatsiyam predstavlen na sayte Ministerstva truda $i$ sotsial'noy zashchity Rossiyskoy Federatsii 2015. Retrieved from http://profstandart.rosmintrud.ru/-/reestr-sovetov-po-professionalnym-kvalifikaciam

NARK. (2015, May 11). Sbornik dokumentov i materialov po nezavisimoy otsenke i sertifikatsii kvalifikatsiy. Retrieved from http://www.nark-rspp.ru/wp-content/uploads/sbornik-po-sertifikatsii.pdf

NARK. (2015, May 12). Sayt Natsional'nogo Soveta po professional'nym kvalifikatsiyam pri Prezidente Rossiyskoy Federatsii 2015. Retrieved from http://nspkrf.ru/home-page/news/item/32-soveti.html

Polzer, J. (2008) Making diverse team. Harvard Business Review, July - August. 20-21.

Russiatourism. (2015, May 10). ofitsial'nyy sayt Federal'nogo agentstva po turizmu Ministerstva kul'tury Rossiyskoy Federatsii 215. Retrieved from http://russiatourism.ru/en

Souty, F. (2003). Competition Problems in the Tourism Sectors, Studies in relation to trade negotiations on tourism services. In WTO (Ed.), Studies in relation to trade negotiations on tourism services. Madrid: WTO.

\section{Copyrights}

Copyright for this article is retained by the author(s), with first publication rights granted to the journal.

This is an open-access article distributed under the terms and conditions of the Creative Commons Attribution license (http://creativecommons.org/licenses/by/3.0/). 